\title{
Bagaimana Pemerintah daerah merespon Fiscal Stress?
}

\author{
Iqbal Lhutfi ${ }^{1)}$, Hamzah Ritchi ${ }^{2)}$, Ivan Yudianto ${ }^{3)}$ \\ ${ }^{122) 3)}$ Fakultas Ekonomi dan Bisnis, Universitas Padjadjaran \\ Jl. Dipati Ukur No.35, Bandung 40132 \\ Email:iqbal17022@mail.unpad.ac.id ${ }^{1)}$, hamzah.ritchi@unpad.ac.id ${ }^{2)}$, ivan.yudianto@unpad.ac.id ${ }^{3)}$
}

\begin{abstract}
This study aims to find out and analyze how the response of the regency/municipality to the occurrence of fiscal stress, which is the inability of local governments to generate sufficient income in the current period to meet their expenditure. This study used descriptive qualitative approach to explore primary data information.. This study used Yogyakarta municipality and Surakarta municipality as research sample, the author conducted interviews with related parties for data collection. The results of this study found that the character of local government entities is an important factor in how the region responds to fiscal stress. Regional Original Income has significant influence on fiscal stress, high or low Regional Original Income will affect the confidence of the region in allocating the budget that will be used for public services. The higher the ability of a region in optimizing local revenue, the smaller the impact of fiscal stress on the area, and vice versa. Another response from local governments to fiscal stress is to allocate appropriate Capital Expenditures in accordance with priorities, so that regional potential will increase and attract investors, so that it will grow the economy of the region, and in the end it is expected to increase regional income in the future. In addition to avoiding fiscal stress, the regional government allocates capital expenditures from Special Allocation Funds (DAK), so that these funds if its increase or decrease have little effect on the fiscal stress, because the capital expenditure funding comes from central government transfer funds.
\end{abstract}

Keywords : Fiscal Stress, Response, Yogyakarta, Surakarta

\begin{abstract}
ABSTRAK
Penelitian ini bertujuan untuk mengetahui dan menganalisis bagaimana respon pemerintah kabupaten/kota terhadap terjadinya fiscal stress yang merupakan ketidakmampuan pemerintah daerah untuk menghasilkan pendapatan yang cukup dalam jangka waktu saat ini untuk memenuhi pengeluarannya. Penelitian ini menggunakan pendekatan kualitatif deskriptif dengan mencoba menggali informasi data primer ke narasumber. Penelitian ini menggunakan kota yogyakarta dan kota surakarta sebagai sampel penelitian, dan penulis melakukan wawancana ke pihak terkait untuk pengumpulan data. Hasil dari penelitian ini menemukan bahwa karakter entitas pemerintah daerah adalah faktor penting bagaimana daerah tersebut merespon terjadinya fiscal stress. Pendapatan Asli Daerah memiliki pengaruh yang signifikan terhadap fiscal stress, tinggi atau rendahnya Pendapatan Asli Daerah akan mempengaruhi kepercayaan diri daerah tersebut dalam mengalokasikan anggaran belanja yang akan digunakan untuk pelayanan publik. Semakin tinggi kemampuan suatu daerah dalam mengoptimalkan pendapatan asli daerah, semakin kecil pula dampak fiscal stress pada daerah tersebut, begitu sebaliknya. Respons lain dari pemerintah daerah terhadap fiskal stress adalah dengan mengalokasikan Belanja Modal yang sesuai sesuai dengan prioritas, sehingga potensi daerah akan meningkat dan menarik investor, sehingga pada akhirnya akan menumbuhkan perekonomian daerah tersebut, dan pada akhirnya diharapkan akan meningkatkan pendapatan daerah di masa yang akan datang. Selain itu untuk menghindari fiscal stress pemerintah daerah mengalokasikan belanja modal berasal dari Dana Alokasi Khusus (DAK), sehingga dana ini apabila mengalami kenaikan atau penurunan tidak terlalu berpengaruh terhadap tingkat fiscal stress daerah tersebut, karena pembiayaan belanja modal tersebut berasal dari dana transfer pemerintah pusat.
\end{abstract}

Kata kunci : Fiscal Stress, Respon, Yogyakarta, Surakarta 


\section{Pendahuluan}

Menghadapi beratnya tantangan dalam menghadapi era globalisasi, melakukan pembaharuan, pemikiranpemikiran yang inovatif dan produktif pada lembaga pemerintah baik pusat maupun daerah merupakan langkah dan sikap yang tepat serta patut mendapatkan dukungan dari semua komponen masyarakat. Sebagai negara yang terus memperbaiki diri, Indonesia berusaha menerapkan paradigma New Public Management (NPM) yang sejalan dengan penerapan otonomi daerah di Indonesia.

Salah satu cara untuk mencapai tujuan otonomi daerah, dapat dilakukan dengan pengelolaan keuangan daerah yang memberikan kebijakan alokasi anggaran daerah lebih besar kepada pemerintah daerah yang bertujuan untuk meningkatkan kesejahteraan masyarakat. Salah satu bentuk kebijakan pemerintah daerah dalam rangka melaksanakan pembangunan yang merata dan berkeadilan adalah melalui penyusunan APBD yang efektif, akuntabel dan transparan. APBD sendiri merupakan instrumen utama kebijakan fiscal yang mempunyai peranan sangat strategis dengan tiga fungsi utama, yaitu fungsi alokasi, distribusi dan fungsi stabilisasi

Dengan dikeluarkannya UU No. 32 dan 34 Tahun 2004 mengenai adanya kewenangan daerah memiliki implikasi dengan adanya desentralisasi fiskal. Kebijakan ini mengisyaratkan pemerintah daerah untuk mengelola sumber daya yang ada di daerahnya secara lebih optimal. Pemerintah daerah yang memiliki potensi sumber daya, mendapat kebebasan untuk meningkatkan kreatifitas dalam mengelola dan mengembangkan potensi sumber daya daerahnya. Namun di sisi lain, akibat kebijakan ini dimungkinkan dapat menjurus pada disparitas (ketimpangan) yang tinggi di setiap daerah.

Fiscal stress atau tekanan fiskal terdiri dari dua kata yaitu fiscal dan stress dalam Bahasa Inggris. Fiscal atau fiskal mempunyai arti dalam Kamus Besar Bahasa Indonesia yaitu anggaran, sedangkan stress atau tekanan yang berarti keadaaan yang tidak menyenangkan. (Hevesi, 2006) menyimpulkan "fiscal stress is a judgment about financial condition-it generally means that a community is having a difficult time financing its operations, and is experiencing growing budgetary problems"; dalam bahasa Indonesia yaitu, tekanan fiskal adalah penilaian tentang kondisi keuangan yang pada umumnya masyarakat mengalami keterbatasan pembiayaan operasi, dan mengalami masalah pertumbuhan anggaran.

Menurut (Dinapoli, 2016) fiscal stress adalah penilaian tentang kondisi keuangan suatu entitas yang harus mempertimbangkan situasi yang unik. Secara umum dapat didefinisikan sebagai ketidakmampuan pemerintah daerah untuk menghasilkan pendapatan yang cukup dalam jangka waktu saat ini untuk memenuhi pengeluarannya. Pengertian-pengertian tersebut juga diperkuat oleh hasil penelitian beberapa peneliti asing yang membahas tentang fiscal stress di beberapa negara. Pendapatan asli daerah yang merupakan salah satu komponen penerimaan pemerintah daerah diindikasikan mempengaruhi tingkat fiscal stress, karena Pendapatan asli daerah ini nantinya akan membiayai belanja pemerintah daerah tersebut. Jika pendapatan asli daerah menurun daerah tersebut akan kesulitan untuk membiayai kebutuhan belanjanya, dan akan semakin bergantung kepada dana transfer dari pemerintah pusat, bahkan jika tidak mencukupi akan menggunakan alternatif pinjaman daerah (Hevesi, 2006).

Salah satu upaya untuk melihat kemampuan daerah dalam rangka self supporting kemampuan keuangan daerah dalam rangka mengurangi ketergantungan terhadap pemerintah pusat, adalah dengan melihat komposisi dari penerimaan daerah yang ada. Semakin besar komposisi pendapatan asli daerah, maka semakin besar pula kemampuan pemerintah daerah untuk memikul tanggungjawab yang lebih besar. Tetapi semakin kecil komposisi pendapatan asli daerah terhadap penerimaan daerah maka ketergantungan terhadap pusat semakin besar. Sedangkan dampak yang dirasakan masyarakat dengan adanya peningkatan penerimaan pendapatan asli daaerah adalah kelancaran pembangunan. Pembangunan meliputi berbagai sektor diantaranya adalah pembangunan jalan, pembangunan fasilitas umum dan fasilitas lain..

Pemerintah daerah yang dapat mengoptimalkan potensi pendapatan asli daerahnya akan memiliki kepercayaan diri untuk mengalokasikan belanja daerahnya, karena memiliki uang yang cukup untuk dibelanjakan, sehingga pemerintah daerah tersebut, akan memiliki tingkat fiscal stress yang lebih rendah. Berbanding terbalik dengan pemerintah daerah yang belum dapat mengoptimalkan potensi pendapatan daerahnya, pemerintah daerah ini akan sulit untuk mengalokasikan belanjanya karena keterbatasan keuangan yang dimiliki (Hevesi, 2006). Sebagai akibat dari hal tersebut mungkin ada anggaran dari SKPD yang dicoret, atau mungkin saja menggunakan alternatif pinjaman daerah untuk menutupi kekurangan keuangan tersebut, kondisi ini menyebabkan pemerintah daerah ini terpapar dampak dari fiscal stress.

Studi tentang fiscal stress di tingkat daerah menjadi semakin penting, terutama pada era otonomi daerah dimana daerah dituntut untuk mampu menyelenggarakan pemerintahannya penyediaan barang dan pelayanan publik bagi warga masyarakatnya. Upaya untuk meningkatkan penerimaan daerah dengan menggali penerimaan baru harus terus dilakukan dalam rangka menutupi anggaran belanja daerah yang semakin meningkat setiap tahun (Firstanto, 2015).

Kebijakan pemerintah daerah dalam menjalankan Anggaran Pendapatan dan Belanja Daerah (APBD) merupakan gambaran langkah kongkrit pemerintah daerah dalam memberikan pelayanan publik. Kebijakan tersebut harus mencerminkan langkah pemerintah daerah dalam perbaikan mutu pelayanannya. Pemerintah daerah dituntut menjadi motor utama dalam menggerakkan perekonomian daerahnya masing-masing agar dapat terus tumbuh dari tahun ke tahun. 


\section{Pembahasan}

Fiscal stress adalah penilaian tentang kondisi keuangan umumnya berarti bahwa pemerintah daerah mengalami kesulitan dalam mendanai operasinya, dan sedang mengalami masalah anggaran yang terus meningkat. Sebaliknya, kabupaten/kota yang sehat secara finansial dapat membiayai layanan secara berkelanjutan - yang berarti bahwa kotamadya dapat menanggung tekanan keuangan jangka pendek (seperti kekurangan pendapatan atau pengeluaran yang tidak terduga) dengan tetap mempertahankan tingkat layanan yang memadai. Mempertahankan kondisi keuangan yang sehat mengharuskan pemerintah daerah untuk merencanakan masa depan dan menyesuaikan diri dengan perubahan sosial ekonomi dan demografis jangka panjang dan dampak ekonomi dari siklus bisnis (Hevesi, 2006).

Sebenarnya tidak ada definisi tekanan fiskal yang diterima secara universal. Para peneliti sering membuat sendiri definisi untuk mengakomodasi fokus penelitian mereka atau mereka dapat memperbaiki definisi yang digunakan di penelitian sebelumnya (Jimenez, 2010). Definisi istilah terkait seperti kondisi fiskal, kondisi keuangan, dan kesehatan fiskal juga tidak jelas dalam literatur saat ini.

Fiscal stress meliputi situasi di mana pemerintah juga tidak dapat memenuhi kewajiban keuangan atau layanannya. Penyebab situasi seperti itu mungkin berbeda di antara pemerintah pusat dan daerah. Penelitian mengidentifikasi sejumlah penyebab potensial fiscal stress juga reaksi terhadap tekanan fiskal.

Pengukuran fiscal stress telah berubah selama bertahun-tahun, tetapi masih belum ada konsensus tentang ukuran terbaik untuk menghitungnya. Studi tentang fiscal stress dimulai di tingkat kota dalam menanggapi masalah keuangan di daerah perkotaan seperti New York dan Cleveland (Savage, 1992). Karena itu fiscal stress seperti itu pada awalnya diukur berfokus pada sumber data kota dan masalah kota. Tujuan utama penelitian tersebut adalah untuk mengidentifikasi kota mana yang paling ditekan secara fiskal untuk menentukan tujuan dan ukuran bantuan federal dan negara bagian serta untuk membedakan secara fiskal investasi yang andal dan tidak andal (Burchell, Robert W., David Listokin, George Sternlieb, James W. Hughes, 1981). Perdebatan tentang pengukuran yang tepat dari tekanan fiskal terfokus luasnya ukuran haruskah itu mencerminkan peristiwa tunggal, penurunan jangka panjang, atau kemampuan kota untuk beradaptasi dengan perubahan sosial ekonomi (Pammer, 1990).

Adanya fiscal stress tidak hanya diindikasikan dipengaruhi oleh pendapatan asli daerah (PAD), tetapi juga dipengaruhi oleh pola/stuktur belanja daerah. (Adi, 2007) memberikan argumentasi bahwa perubahan pola belanja, terutama dengan peningkatan belanja pembangunan menjadi hal yang logis dilakukan dalam rangka peningkatan pendapatan asli daerah. Terkait dengan hal itu, pemerintah daerah diharapkan semakin mendekatkan diri dalam berbagai kegiatan pelayanan publik guna meningkatkan tingkat kepercayaan publik.

Anggaran belanja modal akan semakin meningkat setiap tahunnya, jika tidak adanya penerimaan daerah yang memadai untuk membiayai belanja daerah, maka hal ini akan dapat mempengaruhi terjadinya fiscal stress, mengingat perubahan pembiayaan akan lebih banyak disebabkan adanya tuntutan peningkatan pelayanan publik yang ditunjukkan dengan peningkatan alokasi ataupun terjadi pergeseran belanja untuk kepentingankepentingan pelayanan publik secara langsung dalam hal ini belanja pembangunan (Muda, 2012).

Peningkatan belanja modal untuk pembangunan secara langsung akan meningkatkan anggaran belanja daerah. Belanja modal ini selain ditujukan untuk pengembangan infrastruktur, juga ditujukan untuk berbagai jasa yang terkait dengan pemberian layanan kepada masyarakat. Dengan kenaikan pada belanja modal yang tinggi dan apabila pada saat yang sama pendapatan pemerintah daerah terbatas, maka hal ini akan mengakibatkan terjadinya fiscal stress. Hal tersebut dapat terjadi karena dipicu oleh defisit anggaran dimana pengeluaran lebih besar dari pada pendapatan (Reschovsky, 2003).

Penelitian yang dilakukan oleh (Shamsub \& Akoto, 2004) menunjukkan terdapat perbedaan dalam komposisi pajak dengan pendapatan daerah, dan terdapatnya pengeluaran yang tinggi terkait dengan fiscal stress yang tinggi. Penelitian tersebut menggunakan time series mulai dari tahun 1982-1997 dan analisis regresi berganda digunakan sebagai alat analisisnya. Dalam penelitiannya, Shamsub dan Akoto juga membagi penyebab timbulnya fenomena fiscal stress ke dalam tiga kelompok, yaitu: Menekankan bahwa peran siklus ekonomi dapat menyebabkan fiscal stress, menekankan bahwa ketiadaan persaingan bisnis dan kemunduran industri sebagai penyebab utama timbulnya fiscal stress. Kemudian (Patton, Terry K., 2003) melakukan penelitian di Afrika Selatan menggunakan provinsi-provinsi yang terdapat di Afrika Selatan sebagai sampel penelitiannya. Penelitian ini menggunakan sepuluh indikator yang terbagi menjadi variabel eksogen dan variabel endogen. Sebelum menghitung ukuran fiscal stress, setiap indikator dievaluasi secara terpisah untuk membangun kinerja fiskal provinsi.

(Menchik, 2002) melakukan penelitian di negara bagian Amerika Serikat yaitu California dan Michigan, mengemukakan bahwa kedua negara tersebut juga mengalami fiscal stress. California dan Michigan mengalami defisit anggaran yang besar dan negara tidak mampu untuk menaikkan pajak atau memotong layanan publik secara efektif sehingga mengalami disparitas anggaran. Pro dan kontra fiscal stress setiap negara berbeda-beda, (Menchik, 2002) menyatakan bahwa terjadinya fiscal stress dalam jangka pendek pada kedua negara bagian tersebut dapat membantu pemerintah. Berbeda halnya dengan (Dinapoli, 2016) yang kontra terhadap fiscal stress. Menurut (Dinapoli, 2016) fiscal stress perlu mendapat perhatian agar tiap daerah ataupun wilayahnya mengetahui kesehatan keuangan daerahnya. 
Dengan jumlah Pendapatan Asli Daerah (PAD) yang memenuhi atau melebihi target, proyeksi belanja pada tahun anggaran yang sudah direncanakan oleh pemerintah daerah dapat terpenuhi, dan jika terget pendapatan asli daerah tersebut dapat terlampaui kelebihan dari target tersebut dapat pula dimanfaatkan untuk menutupi kekurangan di sektor lain jika dibutuhkan. Hal ini senada yang disampaikan oleh Ibu Sulistiowati dari BPKAD Kota Yogyakarta, yang menyatakan bahwa:

"Selama ini kita cukup percaya diri, dengan kemampuan yang kita punya kita bisa percaya diri untuk melakukan alokasi belanja. Tapi tetap kita harus menghitung dengan baik bagaimana kondisi keuangan kita. Misalnya itu silpa, jangan sampai kita salah dalam prediksi besaran silpa, sehingga nanti besaran defisit harus sesuai dengan besaran silpa. Sehingga kita harus tau diri, jadi misal kalau prediksi silpa nya kecil ya anggaran yang bukan prioritas harus ditunda atau dicoret."

Hal ini juga terungkap dari wawancara yang penulis gunakan sebagai data pendukung dalam penelitian ini. Ibu Kombar dari BPKAD Kota Yogyakarta menyatakan bahwa:

“....PAD sudah bisa menutupi kekurangan dana transfer, buktinya secara keseluruhan bisa tertutupi, meski dana transfer tidak realisasi $100 \%$, tapi total pendapatan bisa 104\% pada 2017”

Yang disampaikan oleh Ibu Kombar dari BPKAD Kota Yogyakarta tersebut mengindikasikan bahwa apabila Pendapatan Asli Daerah memenuhi target maka daerah tersebut dapat memenuhi kebutuhannya, dan bahkan jika dapat melampaui target maka dapat menutupi kekurangan andai misalnya dana transfer tidak sesuai proyeksi yang direncanakan.

Pemerintah daerah dalam mengoptimalkan pendapatan asli daerahnya punya masing-masing strategi yang dilaksanakan, hal ini terungkap dalam wawancara yang penulis lakukan dengan Ibu Sulistiowati dari BPKAD Kota Yogyakarta, yang menyatakan bahwa:

“...Jadi bagaimana mengemas sektor pariwisata itu meski misalnya mereka jalan-jalan keluar Kota Yogyakarta tapi mereka menginapnya di Kota Yogyakarta, sehingga nanti pajak hotel dan restorannya untuk kita. Dan kita juga sering adakan event pariwisata yang menarik wisatawan untuk datang ke Kota Yogyakarta disekitar malioboro dan pasar beringharjo".

Dalam wawancara tersebut saya mendapat informasi bahwa objek wisata di DIY Yogyakarta justru banyak berlokasi diluar Kota Yogyakarta, sehingga pada akhirnya retribusi dan pajaknya tentu akan mengalir ke kabupaten dan kota yang berada disekitar Yogyakarta, namun dengan kondisi tersebut Kota Yogyakarta memiliki strategi bahwa mereka mengemas sektor pariwisatanya dengan memiliki hotel dan restoran yang baik, sehingga meskipun objek pariwisatanya diluar Kota Yogyakarta, namun wisatawan dapat menginap di hotel dan makan di restoran yang berada di Kota Yogyakarta, sehingga pajak hotel dan pajak restoran beserta komponen pendapatan lain mengalir ke Kota Yogyakarta.

Dalam kondisi kota Yogyakarta yang memiliki pendapatan yang cukup baik dan kepercayaan diri dalam alokasi anggarannya, berdasarkan wawancara yang penulis lakukan, dapat diindikasikan bahwa apabila Pendapatan suatu daerah itu baik maka daerah tersebut akan mengalami dampak fiscal stress yang kecil, dikarenakan daerah tersebut relatif mampu untuk membiayai kebutuhan alokasi anggarannya.

Selain Kota Yogyakarta, penulis juga melakukan wawancara ke BPPKAD Kota Surakarta, dan mendapatkan informasi dari Bapak Adityo, yang menyatakan bahwa:

“...Di solo itu pajak nya 60\% untuk komponen PAD, dan hampir dominannya disitu, dan saya kira untuk kota lain juga dominan disitu. Yang membedakannya itu dari entitasnya, Jakarta dibiarkan tidur pun pajak dan retribusinya pasti akan jalan sendiri, siapapun gubernurnya. Nah dibalik misalnya ke Solo, nah kita "empot-empotan", kota nya itu harus tumbuh dulu untuk PAD nya tumbuh, jadi entitasnya itu dulu yang tumbuh. Nah faktor dominan di daerah solo itu tersier, karena di Solo kita tidak punya sumber daya alam, sehingga struktur PAD nya akan terpengaruh. Untuk men-drive PAD yang rendah untuk bisa naik itu susah mas."

Dalam wawancara dengan Bapak Adityo dari BPPKAD Kota Surakarta, penulis mengindikasikan bahwa Kota Surakarta mengalami kesulitan untuk meningkatkan Pendapatan Asli Daerahnya, hal ini dikarenakan bahwa Kota Surakarta tidak memiliki sumber daya alam, sehingga potensi daerahnya berada di zona tersier dan dibutuhkan usaha yang sangat kuat untuk dapat meningkatkan Pendapatan Asli Daerah. Dalam wawancara ini juga Bapak Adityo menyebutkan bahwa untuk dapat meningkatkan Pendapatan Asli Daerah itu tergantung kepada entitas kota itu sendiri, setiap kota punya potensi dan karakter yang berbedabeda sehingga pengaruh terhadap Pendapatan Asli daerahnya juga akan berbeda.

Bapak Adityo dari BPPKAD Kota Surakarta juga menyatakan:

“.....Jadi kota nya itu harus atraktif dulu, harus support untuk investasi. Kalau alokasi Belanja Modalnya jago, harusnya ini bisa membuat tumbuh kota dan membuat PAD naik, ini masalah utama selama ini. Karena potensinya itu PDRB 35 Triliun, kalau ini tidak diperhatikan investor ga akan mau masuk. Nah ini juga berkaitan dengan daya saing kota nya, kalau daya saing rendah sulit untuk berkembang. Kalau kota yang besar ini udah pasti naik sendiri tanpa diapa-apakan, nah solo kan bukan kota besar".

Dengan karakter Surakarta yang bukan termasuk kota besar Bapak Adityo mengatakan kemampuan Kota Surakarta untuk meningkatkan Pendapatan Asli Daerah terbilang rendah, apalagi dibandingkan dengan Kota besar seperti Jakarta, Bandung dan Kota Besar lain. Kondisi keuangan Kota Sukararta tidak bisa dibilang buruk pun juga tidak bisa dibilang sangat baik, karena Bapak Adityo mengungkapkan bahwa untuk alokasi 
anggaran Kota Surakarta memiliki keterbatasan sehingga terkadang harus memilih antara mana anggaran yang lebih prioritas disamping harus tetap mengakomodasi anggaran di sektor lain yang tetap harus di alokasikan.

Dari data yang sudah diolah oleh penulis dan wawancara yang dilakukan penulis dengan beberapa pihak, dapat diindikasikan bahwa Pendapatan Asli Daerah memiliki pengaruh yang signifikan terhadap fiscal stress terhadap pemerintah daerah. Tinggi atau rendahnya Pendapatan Asli Daerah, akan mempengaruhi kepercayaan diri daerah tersebut dalam mengalokasikan anggaran belanjanya, yang akan digunakan untuk pelayanan publik. Semakin tinggi kemampuan suatu daerah dalam mengoptimalkan pendapatan asli daerah, semakin kecil pula dampak fiscal stress pada daerah tersebut, begitu sebaliknya.

Dalam wawancara dengan Ibu Sulistiowati dari BPKAD Kota Yogyakarta, menyatakan bahwa:

"Jadi itu untuk realisasi itu biasanya tidak 100\% itu di bagian DAK mas, karena ada syarat administrasi tender proyek minimal tanggal berapa, misal kalau tidak selesai sesuai target nanti DAK nya tidak cair mas, nah tapi juga tidak terlalu berpengaruh ketika uangnya tidak cair, karena proyeknya juga tidak terlaksana..."

Bahwa pada faktual di pemerintah daerah, ditemukan bahwa banyak belanja modal yang dialokasikan pemerintah daerah tersebut berasal dari Dana Alokasi Khusus (DAK), sehingga dana ini apabila mengalami kenaikan atau penurunan tidak terlalu berpengaruh terhadap tingkat fiscal stress daerah tersebut, karena pembiayaan belanja modal tersebut berasal dari dana transfer pemerintah pusat. Dalam kasus diatas di Koya Yogyakarta pernah realisasi dana perimbangan tidak memenuhi target dikarenakan syarat administrasi belum terpenuhi sehingga DAK tidak dicairkan, namun meskipun hal demikian terjadi tidak serta merta daerah tersebut mengalami kesulitan dalam alokasi atau terkendala dalam pengalokasian anggaran, karena pembiayaan nya berasal dari Dana Alokasi Khusus. Hal ini senada dengan hasil penelitian (Sugiantini, 2015) di Kabupaten Buleleng Bali yang menyatakan bahwa peningkatan dana alokasi khusus secara fluktuatif sejalan dengan pembangunan di daerah.

Dalam hal ini, jika pembiayaan belanja modal berasal dari pendapatan asli daerah tersebut, mungkin hal ini lebih dapat mempengaruhi tingkat fiscal stress karena pembiayaan belanja modal bergantung pada seberapa mampu daerah tersebut untuk menghasilkan pendapatan asli daerah. Dan artinya bahwa daerah itu harus meningkatkan daya saingnya untuk dapat menaikkan pendapatannya. Dalam wawancara dengan Bapak Adityo dari BPPKAD Kota Surakarta, menyatakan bahwa:

“....kalau untuk men-drive Pendapatan Asli Daerah (PAD) naik harus bener dalam belanjanya, nah disitu kuncinya.."

Bahwa untuk menaikkan Pendapatan Asli Daerah (PAD), hal yang harus dilakukan adalah dengan melakukan strategi yang benar dalam alokasi belanja modal, sehingga nantinya akan menaikkan daya saing sebuah daerah.
Selain itu Bapak Adityo dari BPPKAD Kota Surakarta, juga menyatakan bahwa:

“....bahwa belanja infrastruktur, pendidikan dan belanja kesehatan itu harus diprioritaskan..."

Dari wawancara diatas dapat diindikasikan bahwa untuk menaikkan daya saing kota dan meningkatkan Pendapatan Asli Daerah, maka Belanja Modalnya harus dilakukan dengan benar sesuai prioritas sehingga nanti kota akan menjadi atraktif dan dapat menarik investor, sehingga pada akhirnya akan juga dapat meningkatkan kemampuan kota tersebut. Namun dengan tidak signifikannya pengaruh pertumbuhan belanja modal terhadap fiscal stress, hal ini mengindikasikan bahwa belanja modal pemerintah di jawa belum dapat efektif dan efisien sehingga belanja tersebut belum dapat dioptimalkan pemanfaatannya. Peningkatan Belanja modal di pemerintah daerah se-jawa menunjukan bahwa sebenarnya pemerintah daerah sedang berupaya untuk meningkatkan PADnya dengan melalui pemanfaatan belanja modal.

\section{Kesimpulan}

Respon pemerintah daerah terhadap fiscal stress di kabupaten / kota adalah dengan mengintensifkan dan melakukan intensifikasi dan extensifikasi Pendapatan Asli Daerah (PAD) untuk meningkatkan pendapatan daerah. Beberapa pemerintah daerah memiliki strateginya sendiri untuk meningkatkan pendapatan mereka, tergantung pada karakteristik pemerintah daerah tersebut. Penelitian ini menemukan bahwa karakter entitas pemerintah daerah adalah faktor penting bagaimana daerah tersebut merespon terjadinya fiscal stress.

Respons lain dari pemerintah daerah terhadap tekanan fiskal kabupaten/kota adalah dengan mengalokasikan Belanja Modal yang sesuai sesuai dengan prioritas, sehingga potensi kabupaten/kota meningkat dan menarik investor, sehingga pada akhirnya akan menumbuhkan perekonomian daerah, dan itu diharapkan untuk meningkatkan pendapatan daerah.

\section{Daftar Pustaka}

Adi, P. H. 2007. Kemampuan Keuangan Daerah dan Relevansinya dengan Pertumbuhan Ekonomi. The 1st National Accounting Conference, (Departemen Akuntansi, Fakultas Ekonomi Universitas Indonesia. Jakarta.).

Burchell, Robert W., David Listokin, George Sternlieb, James W. Hughes, and S. C. C. 1981. Measuring Urban Distress: A Summary of The Major Urban Hardship Indices and Resource Allocation Systems. In Cities Under Stress: The Fiscal Crises of Urban America ( by R. W. B. and D. Listokin, Ed.). New Brunswick: NJ: Center for Urban Policy Research.

Dinapoli, T. 2016. Fiscal Stress Monitoring System. Office of the New York State: Comptroller.

Firstanto, R. 2015. Analisis Pengaruh Pertumbuhan Pad, Pdrb, Dan Belanja Modal Terhadap Fiscal Stress 
Pada Kabupaten Dan Kota Di Provinsi Jawa Tengah. Universitas Diponegoro.

Hevesi, A. G. 2006. Analysis of Fiscal Stress in New York State's Cities.

Jimenez, B. S. 2010. Fiscal Stress and the Allocation of Expenditure Responsibilities between State and Local Governments: An Exploratory Study. State and Local Government Review, 41(2), 81-94. https://doi.org/10.1177/0160323x0904100202

Menchik, P. L. 2002. Demographic Change and Fiscal Stress on States: The Case of Michigan. Applied Public Policy Research Program. Lansing: Michigan State University Institute for Public Policy and Social Research.

Muda, I. 2012. Variabel Yang Mempengaruhi Fiscal Stress Pada Kabupaten/Kota Sumatera Utara. Jurnal Keuangan \& Bisnis, 4(1).

Pammer, W. J. 1990. Managing Fiscal Strain in Major American Cities: Understanding Retrenchment in the Public Sector. New York: Greenwood Press.

Patton, Terry K., and A. K. 2003. Financial Analysis of the City of Mesquite Falls, Texas, Using Comprehensive Annual Financial Reports. In Case Studies in Public Budgeting and Financial Management. New York: Marcel Dekker Inc.

Reschovsky, A. 2003. The Implication of State Fiscal Stress for Local Governments. Urban Institute Conference, State Fiscal Crises: Causes, Consequences, \&Solutions., $53706 \quad$ (April). Retrieved from http://taxpolicycenter.org/UploadedPDF/1000612.p df

Savage, J. D. 1992. California's Structural Deficit Crisis. Public Budgeting \& Finance Summer:82-97.

Shamsub, H., \& Akoto, J. B. 2004. State and local fiscal structures and fiscal stress. Journal of Public Budgeting, Accounting \& Financial Management, 16(1), 40-61. https://doi.org/10.1108/jpbafm-1601-2004-b003 